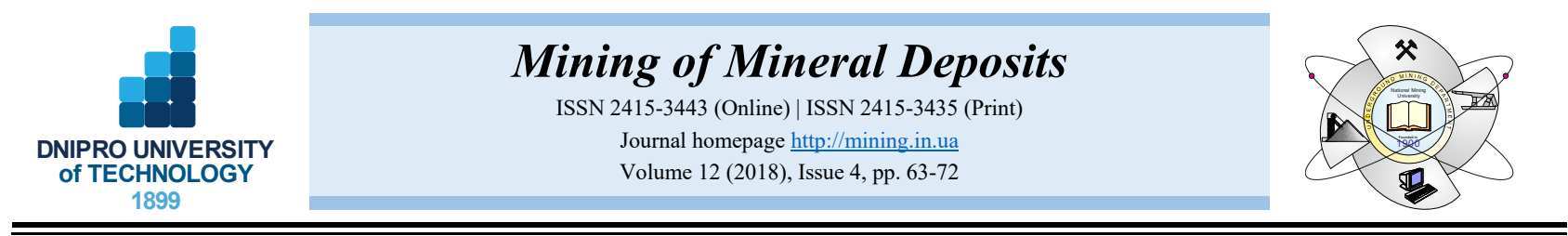

UDC 622.841:504.062

https://doi.org/10.15407/mining12.04.063

\title{
REVIEW OF GEOMECHANICAL PROBLEMS OF ACCUMULATION AND REDUCTION OF MINING INDUSTRY WASTES, AND WAYS OF THEIR SOLUTION
}

\author{
M. Chetveryk ${ }^{1}$, O. Bubnova ${ }^{1 *}$, K. Babii ${ }^{1}$, O. Shevchenko ${ }^{1}$, S. Moldabaev ${ }^{2}$ \\ ${ }^{I}$ Institute of Geotechnical Mechanics named after M.S. Polyakov of the National Academy of Sciences of Ukraine, Dnipro, Ukraine \\ ${ }^{2}$ Kazakh National Research Technical University named after K.I. Satpayev, Almaty, Kazakhstan \\ *Corresponding author: e-mail bubnova@nas.gov.ua, tel.+380965284223
}

\begin{abstract}
Purpose. The identification of geomechanical problems of mining industry wastes accumulation and substantiation of the ways for their solution with the possibility of processing the watery technogenic feedstock by fine classification with dewatering.

Methods. To achieve this purpose, an integrated approach is used in this work, which includes the scientific and technical analysis of research according to wastes accumulation, state statistics data, analytical studies of the strata compaction ratio of aqueous rocks, affecting the subsidence of the earth surface. This also includes the bench experimental studies to establish the dependence of changes in moisture content and the extraction of fine classes in screened products depending on the screening time at shock-vibrating screening by a new method for separating the enrichment wastes before to stockpile them into a pond.
\end{abstract}

Findings. The developed mathematical apparatus has been proposed for determining the parameters of geomechanical processes in technogenic massifs. It has been shown that in order to reduce the technogenic load and manifestation of negative geomechanical processes, it is necessary to reduce the area of land under the waste ponds and the accumulated volumes themselves of mining and enrichment wastes. The dependences have been established of the preliminary enrichment complex on the qualitative parameters of the feedstock and the technological parameters of the equipment. It has been revealed that the mineral stock, formed from wide grain-size classes with a high content of particles less than $0.2 \mathrm{~mm}$, is dewatered up to $18-22 \%$ by traditional methods and is practically not classified.

Originality. A mathematical model has been proposed of screening and dewatering kinetics, which takes into account comprehensively the initial distribution of particles and liquid throughout the height of the screened material layer, segregation, mixing, sifting, vibrational transportation features (rate, multiplicity and number of falls over the period of vibrational transportation) and change in the height of the layer. This model is different due to the account of the mutual influence of classification by coarseness and dewatering.

Practical implications. The represented dependences can be used to predict the development of negative geomechanical processes. The obtained results make it possible by means of a calculation to determine rational parameters of the screen and screening process with dewatering at processing of various feedstock with the use of initial data. The use of technology, which includes a fine classification in wastes processing, will allow: increase the economic efficiency of enterprises; to expand the feedstock base for construction, coke and chemical industries and power industry; to solve the problems of creating additional containers for storing the wastes; to improve significantly the environmental situation in the mining and processing regions.

Keywords: mining industry wastes, geomechanical problems, shock-vibrating screening, preliminary enrichment

\section{INTRODUCTION}

The mining industry is an industry where the nonwaste production has not yet been achieved and the amount of generated wastes is the largest of all industries. Ukraine and Kazakhstan are the countries where the share of the mining industry in total production is
$40-50 \%$. According to the analysis of official statistics data (Committee on Statistics, 2018; State Statistics..., 2018) in terms of volumes of solid minerals extraction (Fig. 1), it follows that in the period of 2003-2008 the volumes of solid minerals production in Ukraine are higher than in Kazakhstan. But since 2009, Kazakhstan has confidently outperformed Ukraine.

(C) 2018. M. Chetveryk, O. Bubnova, K. Babii, O. Shevchenko, S. Moldabaev. Published by the Dnipro University of Technology on behalf of Mining of Mineral Deposits. This is an Open Access article distributed under the terms of the Creative Commons Attribution License (http://creativecommons.org/licenses/by/4.0/),

which permits unrestricted reuse, distribution, and reproduction in any medium, provided the original work is properly cited. 


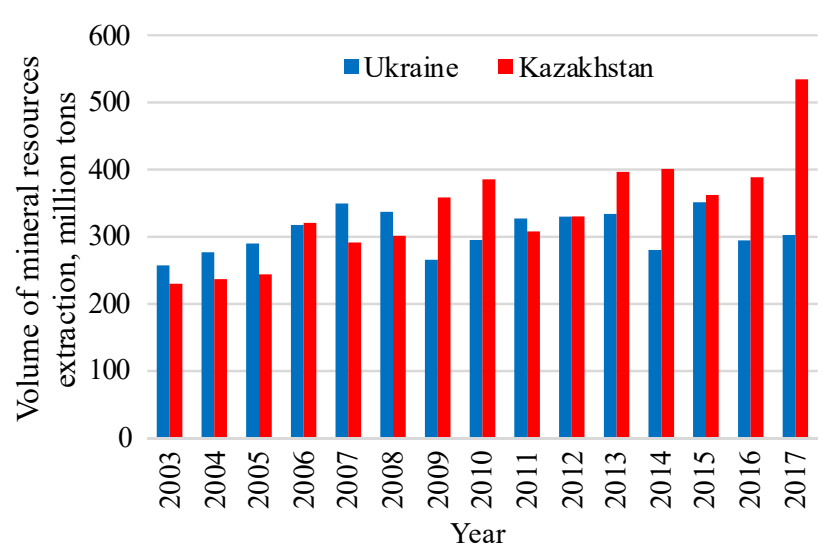

Figure 1. The volumes of mineral resources extraction in Ukraine and Kazakhstan for the period of 2003 - 2017 (excluding oil and gas)

The extraction of all types of solid mineral deposits is invariably accompanied by the formation of wastes in the form of overburden and enclosing rocks located in dumps and waste heaps, slurries and tailings located in ponds. The relative share of mining industry wastes generated annually is $40-80 \%$ in Kazakhstan and $60-85 \%$ in Ukraine. Absolute indicators of the waste volumes generated for the period of $2002-2017$, according to the official statistics data (Committee on Statistics, 2018; State Statistics..., 2018), are shown in Figure 2.

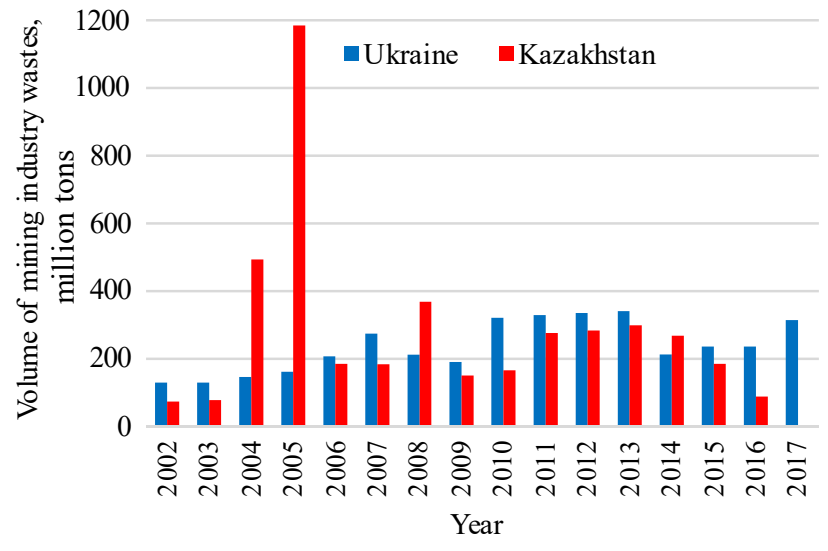

Figure 2. The volumes of mining industry wastes generated for the period of $2002-2017$

As evidenced by the represented data (Fig. 2), in Ukraine, the generated volumes of mining industry waste exceed that in Kazakhstan. Only in certain years (2004, 2005, 2008 and 2014), Kazakhstan is the leader in terms of the generated mining industry wastes (for 2017 the data are not available). To assess the ratio of the generated waste volumes to the volumes of extracted solid minerals, a graph has been plotted (Fig. 3), which shows that in Ukraine this ratio varies from 0.5 to 1.0 thousand tons, and in Kazakhstan from 0.2 to 4.8 thousand tons.

The non-uniformity in the ratio of generated wastes to the volumes of mineral resources extraction is explained by the need to carry out stripping operations in certain years in a larger volume in order to prepare reserves for mining. It can also be noted that in Kazakhstan there is a tendency to a decrease in the ratio of waste volumes to extraction volumes (since 2011), and in Ukraine, on the contrary, to an increase.

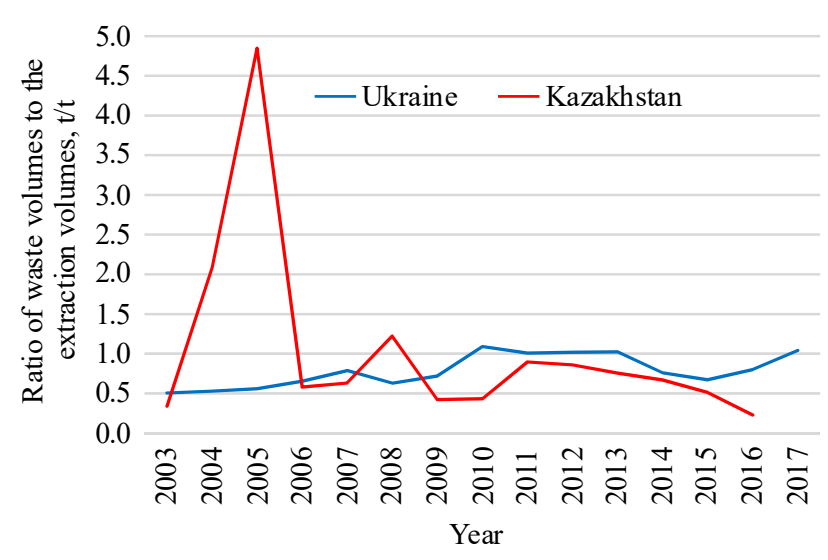

Figure 3. The ratio of the generated waste volumes to the volumes of extracted mineral resources for the period of $2003-2017$

The waste generation in itself is not a problematic issue, its accumulation is dangerous. So in Ukraine at the beginning of 2018 , more than 12.4 billion tons of mining industry wastes have been accumulated. If the specific load of wastes at an average in Ukraine is $2-3$ thousand tons $/ \mathrm{km}^{2}$, then in mining areas it reaches up to $8-20$ thousand tons $/ \mathrm{km}^{2}$. At the regional level, the bulk of wastes is generated in the Dnipropetrovsk, Donetsk, Zaporizhzhia, Luhansk, Lviv regions (Petlovanyi \& Medianyk, 2018). In Kazakhstan, the bulk of mining industry wastes is concentrated in Pavlodar and Karaganda regions (Committee on Statistics, 2018).

The technogenic objects are displacing and replacing natural ones, the natural balance is disturbed, the natural environment has undergone significant changes (the pollution of atmosphere, water environment and soil, destruction of the geological structure, changes in the properties of rocks and soils, disturbance of the hydrodynamic and hydrochemical regimes of the underground and surface waters, destruction of flora and fauna).

In addition to the disturbance of soils and their withdrawal from agricultural use, the technogenic massifs of mining industry wastes have a negative impact on the surrounding natural environment, the loss of the natural properties of which leads to the earth surface subsidence, landslides, the formation of sinkholes, the development of flooding in the adjacent areas (Chetverik, Babiy \& Bubnova, 2013).

The purpose of this work is to identify the geomechanical problems of mining industry wastes accumulation and to substantiate the ways of their solution.

\section{THE OVERVIEW OF RESEARCH}

The issues of the earth surface subsidence are well studied through proper empirical models by statistical analysis of both fuzzy methods and artificial neural network (Decka, Baroudib, Hosnic, \& Gueniffey, 2018).

The problems of landslides formation are not less well studied. At the same time, the scientists take into account the conditions for the natural and artificial rocky slopes formation, the presence of geological disturbances, the height of the seams (layers), the angles of slopes and other conditions that causes the sliding of the rock massif (Zhang et al, 2018). In addition, there 
are scientific works that consider the formation of landslides as a result of subsidence of rocks under dumps with account of the amount of precipitation $(\mathrm{Wu}, \mathrm{Lan}$, Gao, Li, \& Yang, 2015).

The geomechanical problems of inside dumps stability are studied in the work (Rakishev, Seituly, \& Kovrov, 2014), and the criteria for landslides formation in the dumps are studied in the work (Shashenko \& Kovrov, 2016). The authors propose to consider a number of factors of natural, technogenic and technological nature in assessing the dumps stability with account of changes in the geomechanical properties of their bases.

In a number of scientific publications it is noted the need to take into account the wetting of soils when determining their subsidence under loading (Garakani, Haeri, Khosravi, \& Habibagahi, 2015), as well as the amount of water content in determining the deformation behaviour of soils (Malizia \& Shakoor, 2018).

Also in the work (Kukemilks, Wagner, Saks, \& Brunner, 2018), it is pointed out the importance of taking into account of changes in the hydrogeologic regime when predicting the development of landslide formation. The authors of the work (Christelis \& Hunges, 2018) propose to perform the modelling of hydrogeologic regime change with the use of the Monte Carlo method, which shows the best results in integrated modelling of such processes. At the same time, at present in the world practice, it is not taken into account the change in the hydrogeological, hydrologic regimes associated with the accumulation of dumps and slurry storages, as well as the surface subsidence under such technogenic objects, which is connected with such a change.

The problems of reducing the waste volumes are being studied very actively in recent years. In the work (Pavlychenko \& Kovalenko, 2013), it is shown the presence of heavy metals in wastes from coal mining, which, with the application of appropriate technologies can be extracted from stockpiled rocks. A similar approach is represented in the work (Medvedeva, 2015), where it is proposed to introduce the accompanying extraction of a valuable component from the site adjacent to the dumps of slurry storage beach together with the combined waste storage technology, which will allow to extract a part of valuable component remaining in the enrichment wastes at the stage of filling the storage, and, respectively, reduce the volumes of stockpiled wastes. The authors of the work (Zhang, Spanjers, \& van Lier, 2013) propose to extract phosphorus from slurries in order to reduce the amount of wastes and increase the resource supply of the enterprise.

The wastes from mineral resources extraction and processing, located in the settling sumps and ponds of mining and processing enterprises, occupy the special place (Nadutyy, Malanchuk, Malanchuk, \& Korniyenko, 2015). This wastes, on the one hand, have a significant ecological burden on the environment, on the other hand, they are potential sources of ferrous, non-ferrous, precious metals, rare metals, non-metallic and energy feedstock. The prospects for their industrial development can be linked only with the creation of efficient technologies for their processing, based on the most complete information about the material composition and structure of the technogenic feedstock.
To take into account the peculiarities of changes in the properties of minerals, including those aimed at increasing the degree of their contrast ratio in the technological regime, it should be borne in mind that they are formed and manifest themselves in a wide granulometric factor range, both during preparation and in various points of the enrichment scheme. When fine grinding, the constitution of minerals can significantly change (up to the occurrence of newly formed phases, amorphization phenomena, etc.), and the surface properties, etc.

Thus, as a result of the performed analysis, it has been established that the geomechanical processes occurring in the natural environment in the areas where large technogenic objects of the mining industry are located, are not enough well studied, and the problems have not been solved of minimizing the volumes and areas occupied by them.

\section{GEOMECHANICAL PROCESSES IN THE NATURAL ENVIRONMENT CONTAINING TECHNOGENIC OBJECTS}

The formation and presence of technogenic massifs within the natural environment affects negatively the natural hydrogeologic conditions. This is manifested in change in the area of nutrition, movement and discharge of groundwater, as well as in formation and deformation of the depression pits, significantly large by area. The disturbance of the hydrologic regime of the territories, in contrast to the disturbance of the rock massif and earth surface, is a more dynamic factor that can dramatically increase the impact on the environmental of other factors. As a result, the indirectly disturbed lands are formed (flooded, marshy, additional subsidence occurs, and the fertile rocks properties change).

In modern engineering and geological surveys, it has been established that in a large area of the mining region territories, where there is an extremely high level of technogenic load, the phreatic aquifers are almost completely eliminated. According to the previously performed studies (Bubnova, 2017), it has been established that during the drawdown in the process of conducting the drainage works in order to prepare the deposit for mining operation and during the extraction of mineral resources, the rock massif is dewatered, as a result of which the layers of aqueous rocks are compacted. This leads to the development of secondary deformation processes, manifested in the displacement of the earth surface and its subsidence over a large area.

When compacting the rocks of the aquifer, the value of subsidence is determined by the following author's formula:

$\eta_{4}=m_{a}\left(\sqrt[3]{\frac{e_{0}}{1+e_{0}}}-\sqrt[3]{\frac{e_{i}}{1+e_{i}}}\right)$

where:

$\eta_{4}$ - the value of subsidence of the water-bearing rocks layer;

$m_{a}-$ the thickness of aquifer, $\mathrm{m}$;

$e_{0}-$ the initial porosity factor;

$e_{i}-$ the porosity factor and the pressure corresponding to the $i$-th load stage. 
One can judge about a change in the porosity factor of aquifers from a decrease in the water level in observation boreholes or from subsidence of the earth surface. With a decrease in the water level in the boreholes in the process of drawdown, the ratio of increased pressure on water-bearing rocks to the original pressure is the same as the ratio of water levels: of the sum of initial level and the value of decrease in the level to the initial one. Then the dependence of the porosity factor on change in the water level in the boreholes can be represented as follows:

$e_{i}=e_{0}-C_{H} \ln \left(\frac{H_{0}+\Delta H}{H_{0}}\right)$,

where:

$C_{H}$ - the compression factor (the slope ratio of semilogarithmic curve to the pressures axis);

$H_{0}$ - the height of the water column in the borehole at the beginning of observations from the water table to the aquifer, which is dewatered, $\mathrm{m}$;

$\Delta H$ - a change in water level in the borehole relative to the original one, $\mathrm{m}$.

The expression (1) takes into account the reduction in the thickness directly of the aqueous rocks layer. The subsidence of a surface will be somewhat smaller. It will be taken into account as the settlement factor $\mathrm{q}_{0}$, as it is in the underground coal mining.

Then, with account of the settlement factor, the expression (1) takes the form:

$\eta_{4}=q_{0} m_{a}\left(\sqrt[3]{\frac{e_{0}}{1+e_{0}}}-\sqrt[3]{\frac{e_{i}}{1+e_{i}}}\right)$

Thus, knowing the value of drawdown in the boreholes, and the aquifer, due to which it happens, a change in the porosity factor can be determined by expression (2), and the value of the earth surface subsidence can be determined with the use of expressions (1) or (3).

To calculate the area of the geomechanical processes development, which are caused by drawdown, it is proposed to determine the radius of the depression pit by the author's formula:

$$
R=r \cdot e^{\frac{\pi \cdot K_{p}\left(H_{0}-H_{c} \pm 0.5 A\right)}{Q}},
$$

where:

$r$ - the radius of lands disturbed by mining operations, m;

$Q$ - the daily mine drainage / open-pit mine drainage, $\mathrm{m}^{3} /$ day;

$K_{p}$ - the average coefficient of permeability in rocks of quaternary deposits and carbon, cub. m/day;

$H_{C}, H_{0}$ - the height of the water level at the beginning and at the end of the depression pit, respectively;

$A$ - the amplitude of seasonal variation in underground water level (with the "+" sign during the spring and autumn increase, with the "-" sign - in the summerwinter decrease).

The proposed mathematical apparatus has been tested at actual data based on field regime observations for the Nikopol - Marhanets and Kryvyi Rih basins with a good convergence of the results.
As can be seen from the above expressions, in order to reduce the technogenic load and the manifestation of negative geomechanical processes, it is necessary to reduce the area of land under the waste ponds and the accumulated volumes themselves of mining and enrichment wastes.

\section{THE TENDENCY FOR MINING WASTES REDUCTION}

The open method of mineral resources extraction is impossible without stripping operations. However, in addition to soft and primary overburden (dead) rocks, this volume includes losses of extracted mineral stock and associated mineral resources. So, in the production face, when mining the contact areas, the significant losses and dilution of the mineral resources occur. This problem is being studied by many experts (Shashenko \& Kovrov, 2016; Petlovanyi \& Medianyk, 2018; Zhang et al, 2018). The different ways have been developed to reduce them. However, despite the significant scientific and technical achievements, the diluted ores are supplied to processing enterprises, which significantly increases the production cost of final products. Therefore, the diluted ores are sent to the dumps. In addition, the following losses are:

- balance losses, which are controlled, recorded and written off by special services;

- off-balance losses, which are not subjected to account.

About the amount of losses incoming into the dumps, one can judge by official data from the write-off protocols, and it should not exceed $2-4 \%$, depending on the geology. However, in practice, it is very difficult to keep these restrictions.

The parameters of open-pit mining affect the amount of losses (Babii, 2011):

- geological (complex structure of the geological stratum, ore delineation, thin ore bands, invisible contact zones, dradge, etc.);

- technical (excavation machinery with a high unit capacity);

- technological (the rocks mixing during the explosion, cut-off grade of the valuable component, the inability to use selective extraction, losses during rehandling, transloading, dry enrichment wastes).

Thus, the technogenic deposits, available for extraction, are formed in dumps from losses of mineral resources. To do this, they should be processed. It is promising to use the technology of preliminary enrichment (roughing) of mine rocks with magnetic inclusions and associated mineral resources extraction directly at dumps. This technology is designed to reduce the losses of mineral resources and improve the environmental situation at the mining enterprises by reducing the volumes of dumps.

The technology involves the processing of the mined rock with the use of a preliminary enrichment complex (Babii, 2011). This complex includes a dry method of enrichment (gravitational, magnetic, radiometric or electric). The main parameter that determines the selection and application of mineral-processing equipment is the granulometric composition of the ore. In this regard, it is necessary to preliminarily subject the primary rock for- 
mations to mechanical coarse crushing. The stationary, semi-stationary and mobile crushing machinery have been developed for rock crushing, which can be combined by performance with separators. In addition, the technological schemes used for mining, transporting and storing overburden rocks, modern developments in the field of enrichment, as well as design solutions for crushing and mineral processing equipment, contribute to the development of technology for preliminary enrichment of the ore. For iron-ore open-pit mines, it is rational to use magnetic separators, which process the mined rock after mechanical coarse crushing with a coarseness of $450-0 \mathrm{~mm}$ (Babii, 2011). The annual production capacity of the preliminary enrichment complex $Q_{K}$ determine by the author's dependence:

$Q_{K}=Q_{S} K_{P} K_{O} K_{I} T_{C} K_{C} n_{c} K_{d}$, tonne

where:

$Q_{S}$ - the performance of the separator for dry magnetic separation, tonne;

$K_{P}$ - the coefficient, which takes into account the time spent on the production of planning and preparation works;

$K_{O}$ - the coefficient, which takes into account the waiting time;

$K_{I}-$ the coefficient, which takes into account the nonuniformity of mined rock delivery for processing by the preliminary enrichment complex;

$T_{C}$ - the number of labour hours per shift;

$K_{C}$ - the conversion factor for the 12-hour shift;

$n_{c}$ - the number of working shifts per a day;

$K_{d}$ - the number of working days per a year is taken according to the work schedule of the open-pit mine.

The production capacity of the complex is calculated by the dependence, generally accepted among the engineers, between the yield of the magnetic product and of the tailings. Within the studied problem, the author proposed to interpret the formula through the preliminary enrichment products: by yield of the magnetic product $\gamma_{m}^{p}$ and dry tailings $\gamma_{t}^{p}$ :

$Q_{K}=\gamma_{m}^{p} Q_{m}+\gamma_{t}^{p} Q_{t}$, tonne,

where:

$Q_{m}$ - the magnetic product yield rate, tonne;

$Q_{t}-$ the tailings yield rate, tonne.

In turn, to perform research on the influence of geological and technical parameters, the formula of a magnetic product yield is interpreted through the preliminary enrichment products:

$\gamma_{m}^{p}=\frac{\alpha-\theta}{\beta_{p}-\theta} \cdot 100$, tonne,

where:

$\alpha$ - the content of the valuable component in the original mined rock, $\%$;

$\beta_{p}$ - the content of the valuable component in the extracted magnetic product, $\%$;

$\theta$ - the content of the valuable component in the preliminary enrichment wastes, $\%$.

The results of the author's research for determining the patterns of changes in the production capacity of the complex depending on the technical parameters of the equipment (declared by the manufacturer) and the quality characteristics of the processed mineral stock (averaged over the open-pit mines of the Kryvyi Rih iron-ore basin), are represented in Figures $4-6$.

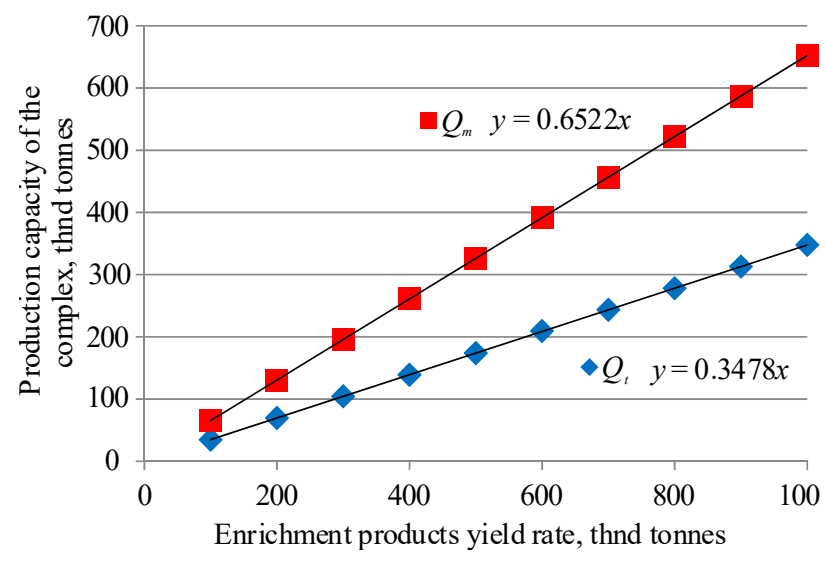

Figure 4. Dependences of the production capacity of the preliminary enrichment complex on the technical parameters of the equipment: $Q_{m}$-the magnetic product yield rate, tonne; $Q_{t}-$ the tailings yield rate, tonne

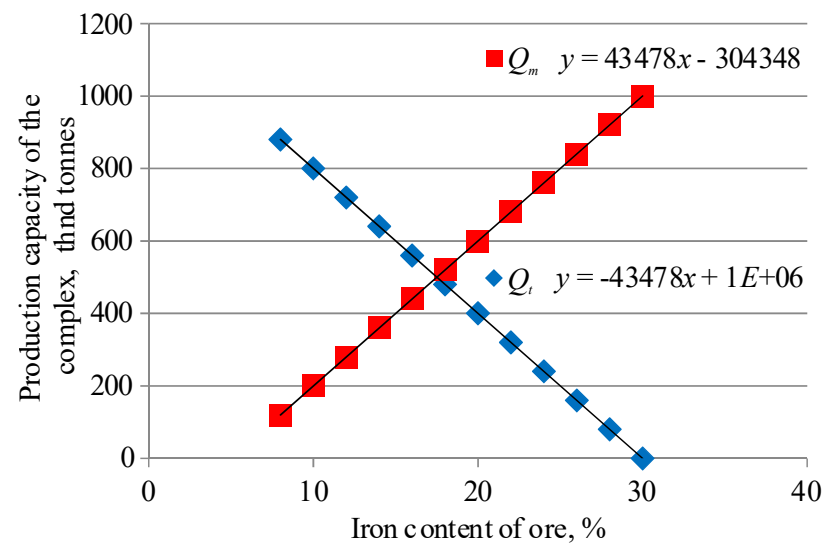

Figure 5. Dependences of the production capacity of the preliminary enrichment complex when changing the iron content in the mined iron ore

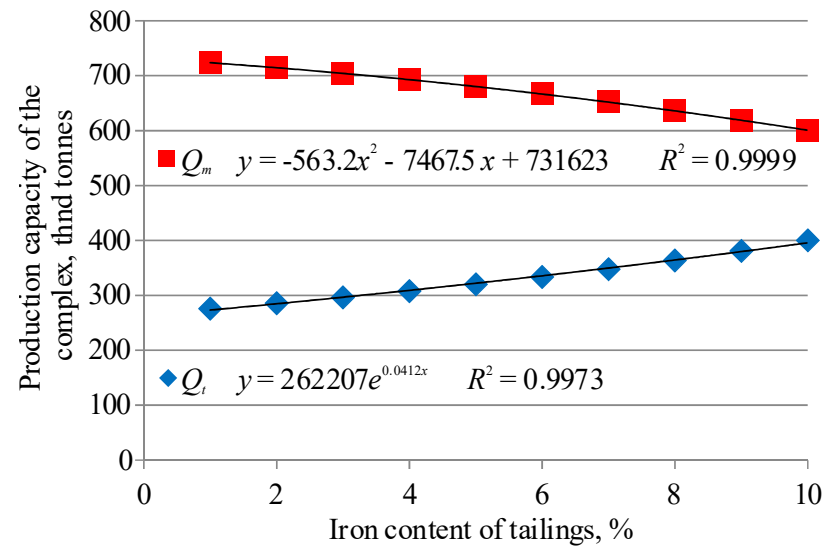

Figure 6. Dependences of the production capacity of the preliminary enrichment complex when changing the iron content in the processing tailings 
The processing efficiency of primary overburden rocks at the dump after the stage of mechanical coarse crushing is determined by the linearly proportional dependence of the magnetic product yield after preliminary enrichment. As it is seen from the first graph in Figure 4, this dependence has a linear form and depends on the technical parameters of the used equipment. Whereas the qualitative characteristics of the magnetic product are determined by a linear dependence on the content of the valuable component in the feedstock, by a polynomial dependence - on the content of the valuable component in the preliminary enrichment tailings. Thus, by using the proposed technology, it is possible to reduce by $30 \%$ the supply of rocks to dumps.

\section{THE TENDENCY FOR ENRICHMENT WASTES REDUCTION}

The methods based on the use of water, the so-called wet methods of enrichment, are most widely used in mineral resources enrichment. However, the finished products must have a minimum moisture content hence, there is a need for dewatering. The similar problems also arise in additional enrichment of wet technogenic feedstock (ore, coal slurries, screenings, etc.), consisting mainly of particles less than $1-5 \mathrm{~mm}$ in size (fine-grained feedstock).

Analysis of recent research (Ettmayr, Stahl, Keller, \& Sauer, 2000; Wodzinski, 2003; Shevchenko, Shevchenko, \& Lebed, 2016), has shown that dewatering of fine and small particles (less than $0.25 \mathrm{~mm}$ in size) causes the greatest difficulties, because, the products formed from them have a highly developed surface, which interacts actively with water, retains significant its amounts due to the highly developed surface of the particles and the acting capillary and electrostatic forces. The porosity and permeability of these media is usually low. With a decrease in the particle coarseness in the products, the binding energy of the liquid with the solid surface increases, in other words, the resistance to water flow increases in the pore space. The higher this energy, the more difficult to separate the liquid (Shevchenko, Shevchenko, \& Lebed, 2016). Therefore, it is most difficult to remove water bound by capillary forces (surface tension forces). It follows that the known technologies do not provide effective dewatering. In this regard, the problem of moisture removal can be solved by improving the existing technologies.

A mechanical dewatering is the cheapest and most commonly used method (Ettmayr, Stahl, Keller, \& Sauer, 2000; Wodzinski, 2003; Shevchenko, Shevchenko, \& Lebed, 2016). Improving the efficiency of removing moisture from fine products by mechanical methods allows to save energy consumed during their thermal bringing to the state of commercial moisture content. For these purposes, a wide variety of equipment is used with different principles of operation: vibrating screens, centrifuges and filters. Vibrating screens are simpler and cheaper than centrifuges and filters. In addition, even in cases when centrifuges and filters are used, vibrating screens are set before them.

At the same time, as the practice has shown (Lapshin \& Shevchenko, 2013), the traditional methods make it possible to screen effectively only materials with particle sizes of more than $1 \mathrm{~mm}$, and reduce the moisture content of the finished product to only $18-22 \%$ depending on the coarseness (for comparison, the permissible moisture content during transportation is $8-10 \%$ ). The screening of materials with a coarseness of $0.5-1 \mathrm{~mm}$ by traditional methods does not give high results, and with a particle size of less than $0.2 \mathrm{~mm}$ it is almost impossible. It is of particular difficulty the processing of wide grain-size classes, when together with dewatering it is necessary to separate fine classes (as a rule, off-test product) and to dewater the finished (oversize) product as much as possible (Lapshin \& Shevchenko, 2013).

The author's research results of the waste properties (case study of the construction sands (Liubymivskyi open-pit mine) and coal slurries (Kurahivska TSOF)) indicate the fundamental possibility of obtaining a commercial product having a consumer demand by means of fine classification by coarseness of $0.15-0.2 \mathrm{~mm}$ with a simultaneous dewatering (Figs. 7 and 8), which will allow to reduce the volumes of stored wastes.

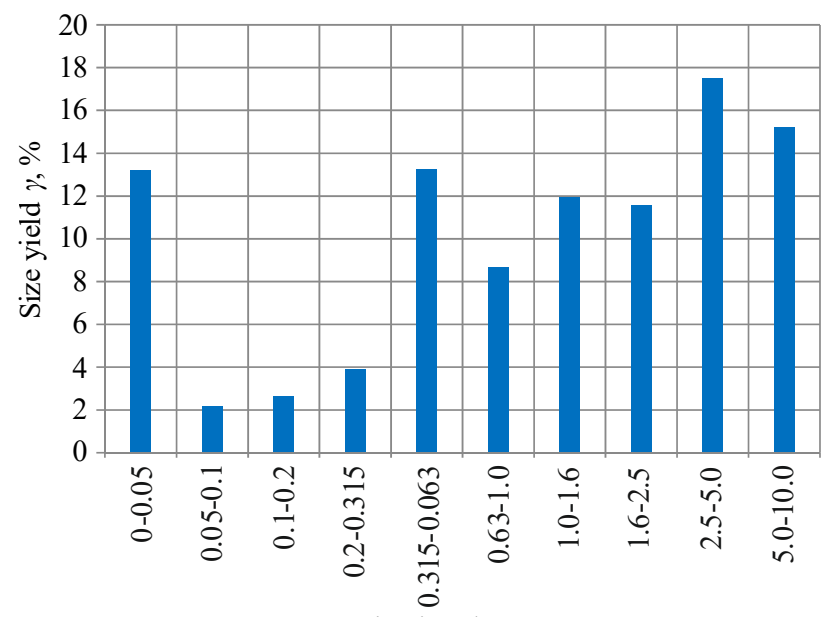

Grain-size classes, mm

Figure 7. The properties of construction sands (stone screening dust)

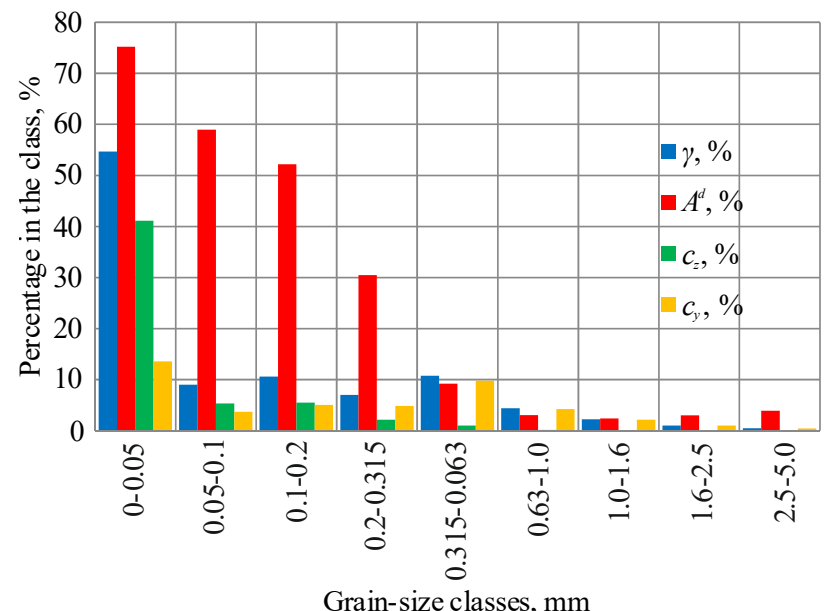

Figure 8. The properties of coal slurries: $\gamma$-size yield; $A^{d}$-ash-content in the class; $c_{z}$-percentage of ash in the class; $c_{y}$-percentage of coal in the class

At the same time, fine classification according to the specified coarseness with high efficiency for narrow and wide strips of the separated classes of dry bulk materials 
is a problem. The pulp classification with a solids content according to these classes is even more difficult task, since its solution is complicated by the highly developed surface of fine particles and the acting capillary forces, as well as the additional viscosity of the liquid and clay inclusions dissolved in it (Lapshin \& Shevchenko, 2013). For these purposes, the Ukrainian industry does not produce the serial equipment. At the same time, many authors point at the existing reserves for improving the efficiency of the dewatering process and classification of fine products namely by the way of mechanical impact on them, as the most realizable and relatively inexpensive way (Ettmayr, Stahl, Keller, \& Sauer, 2000; Wodzinski, 2003; Shevchenko, Shevchenko, \& Lebed, 2016). Hence, the improvement of vibrating screens is of close attention, which will ensure an increase in the efficiency of processing technologies, the quality of feedstock, energy saving and resource saving, as well as a reduction in the harmful effect on the ecology.

At thin and ultrafine screening, the removal of liquid requires the substantial energy consumption, since surface tension forces, exceeding the gravity force significantly, resist this process. To overcome these forces on the working surface, accelerations are necessary in the existing serial vibrating screens, which significantly exceed their level.

Currently, the developments and individual tests are being carried out in this direction. Institute of Geotechnical Mechanics named after M.S. Polyakov of the National Academy of Sciences of Ukraine has developed a new method of shock-vibrating screening (Lapshin \& Shevchenko, 2013), at which, in order to expand the spectrum of impact on the screening surface and the processed feedstock, it is proposed to excite the screening surface with 'double' shocks. Initially, the first shock is made, which contributes to the detachment of feedstock from the screening surface and its loosening, then at the flight phase a second shock is made, which provides an additional acceleration for the screening surface, which ensures its cleaning from particles stuck in the holes, as well as menisci rupture of the liquid. It is important to note that when the second shock is applied, the screened feedstock does not prevent the removal of particles and liquid. Additionally, an activator and various disintegrating elements (DE) were used to intensify the screening process (Lapshin \& Shevchenko, 2013).

To assess the effectiveness of the new method in shock-vibrating screening, the experiments have been carried out to establish the patterns of moisture content change depending on the structural and operating parameters of the screen and the properties of the feedstock (granulometric composition, narrow and wide grain-size classes, density), the influence of moisture content change on the classification and rational parameters of the screening process with dewatering. The researches were conducted in laboratory conditions on the model of shockvibrating screening. The construction sands of Liubymivskyi open-pit mine were used for the experiments.

The author's dependences of change in moisture content $(W)$ and extraction $(\varepsilon)$ classes in screened products (oversize and undersize) depending on screening time $(t)$ in shock-vibrating screening by a new method, are shown in Figure 9. (a)

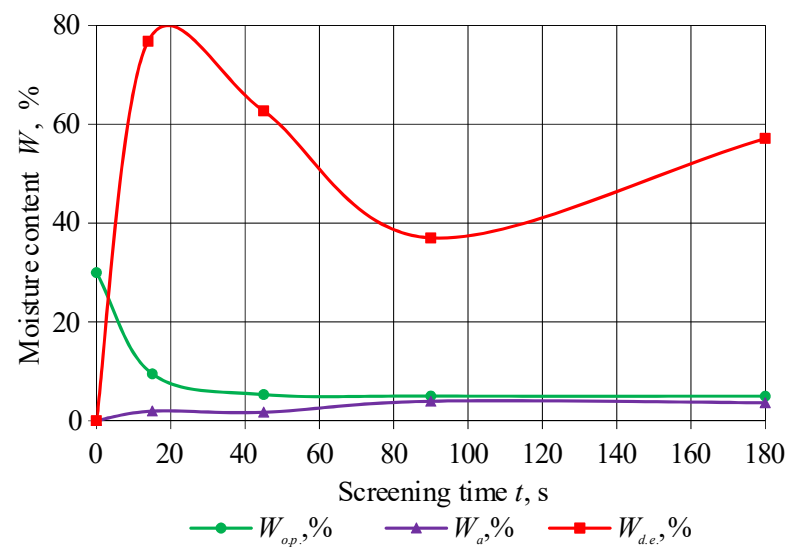

(b)

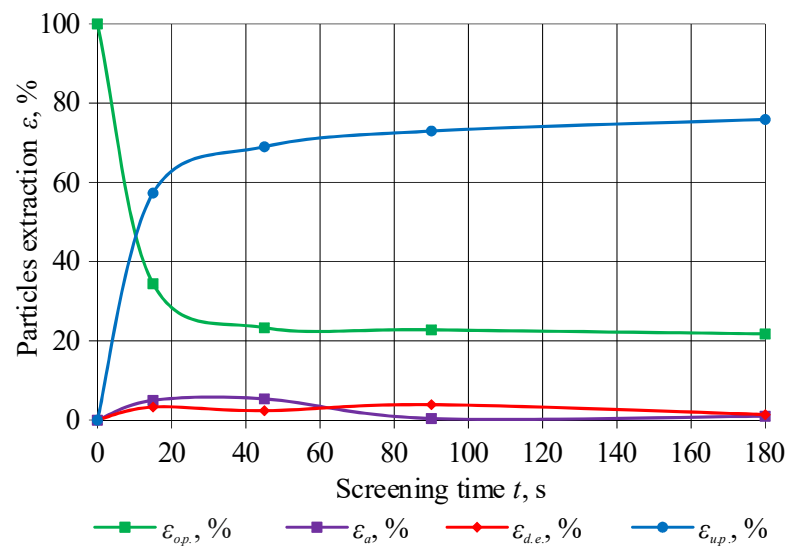

(c)

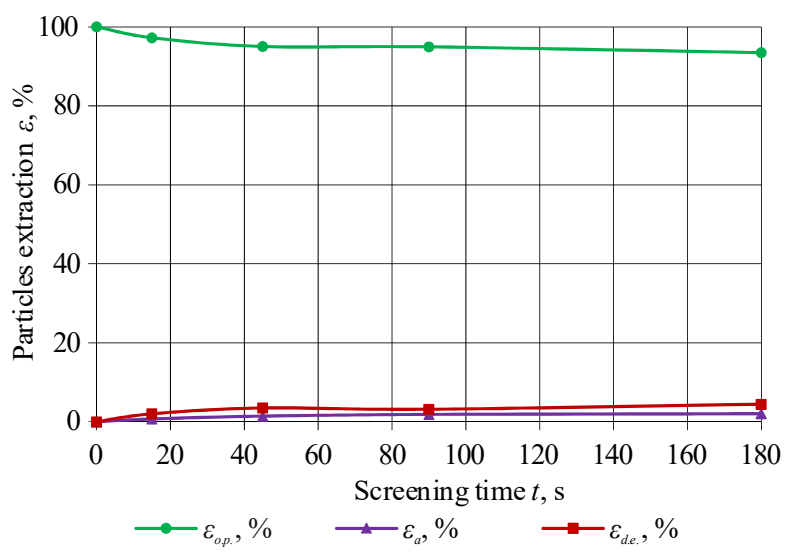

Figure 9. Change in moisture content (W) and extraction of (c) classes in products depending on screening time (t): (a) change in moisture content W; (b) change in extraction of $(\varepsilon)$ class $+0-0.1 \mathrm{~mm}$; (c) change in content of $(\varepsilon)$ class $+0-10.0 \mathrm{~mm}$

The application of shock-vibrating screening by a new method made it possible to process the feedstock containing small grain-size classes, which are not classified and dewatered with the moisture content of $18-20 \%$ by using traditional methods. The moisture content has been reduced from $30 \%$ to $8-10 \%$, and extraction of the class $-0.1 \mathrm{~mm}$ into the undersize product has been increased by $75-80 \%$. 
Based on the obtained data, the mathematical models have been created for calculating the parameters of the shock-vibrating screen, the dewatering processes of mineral stock and the kinetics of screening and dewatering (Lapshin \& Shevchenko, 2012), as well as the numerical experiments have been performed to determine the technological parameters of dewatering and separation by coarseness.

The created mathematical models make possible to calculate the performance of screens, screening efficiency and dewatering. Based on the calculation, the technological parameters of screening and dewatering are determined: extraction of particles with a specified coarseness into the undersize product, the undersize product yield rate, the oversize product mass, the liquid mass in the oversize product, and the moisture content of the oversize product. The efficiency of screening is assessed by extraction of the particles with a specified coarseness into the undersize product and moisture content of the oversize product. The novelty of the mathematical model is in taking into account the mutual influence of the classification by coarseness and dewatering.

Having compared the experimental and calculated data results, it was established that they differ by no more than $15 \%$, in other words, the formulas of mathematical models with a confidence coefficient of 0.95 describe adequately the experimental data. These results make it possible by means of a calculation and with the use of initial data to determine rational parameters of the screen and screening process with dewatering at processing of various feedstock.

\section{CONCLUSIONS}

The represented results of scientific research should reasonably be used to manage the state of the natural environment in mining regions, in further research of the problem of technogenic massifs occurrence, in the projects for the revegetation of open-pit mines and dumps, various types of pits and within the shift troughs, as well as in additional enrichment of wastes from mining and processing of mineral stock.

It is shown that the presence of technogenic massifs huge in area and volume leads to a change in the properties of the natural geological environment in which they are located: the earth surface subsidence, flooding, dehydration occur, and landslides are formed. The only direction to reduce the technogenic load is to reduce the volumes of stockpiled mining industry wastes.

It is proposed to perform the rock processing at waste dumps, while the processing efficiency of the primary overburden rock at the dump after the stage of mechanical coarse crushing is determined by the linearly proportional dependence of the magnetic product yield after preliminary enrichment and depends on the technical parameters of the used equipment. Whereas the qualitative characteristics of the magnetic product are determined by a linear dependence on the content of the valuable component in the feedstock, by a polynomial dependence on the content of the valuable component in the preliminary enrichment tailings. This technology is designed to reduce the losses of mineral resources and improve the environmental situation at the mining enterprises by reducing the volume of dumps.
It is proposed to subject the wastes of enrichment to a fine classification. It has been revealed that the mineral stock, formed from wide grain-size classes with a high content of particles less than $0.2 \mathrm{~mm}$, is dewatered up to $18-22 \%$ by traditional methods and is practically not classified. It has been confirmed the possibility of processing mineral stock by a new method of shock-vibrating screening based on the obtained dependences, as a result of which the moisture content was reduced from $30 \%$ to $8-10 \%$, and the extraction of the class $-0.1 \mathrm{~mm}$ into the undersize product was increased by $75-80 \%$.

The developed mathematical models for calculating the parameters of the shock-vibrating screen, the dewatering processes of mineral stock and the kinetics of screening and dewatering, make possible by means of a calculation and with the use of initial data to determine the rational parameters of the screen and screening process with dewatering at processing of various feedstock. It is possible on their basis to synthesize a rational process of screening and dewatering, as well as to analyse the existing screens operation in order to identify ways of their modernization. The use of technology, which includes a fine classification in wastes processing, will allow: increase the economic efficiency of enterprises; to expand the feedstock base for construction, coke and chemical industries and power industry; to solve the problems of creating additional containers for storing the wastes; to improve significantly the environmental situation in the mining and processing regions.

\section{ACKNOWLEDGEMENTS}

The authors express particular gratitude to the management and employees of PJSC "United MiningChemical Company", Vilnohirsk Mining Metallurgic Integrated Plant, branch of TSOF Pavlohradska, DTEK Pavlohradvuhilia PJSC for providing the factual materials (enrichment wastes) to conduct research under laboratory conditions.

\section{REFERENCES}

Babii, E.V. (2011). Tekhnologiya predobogascheniya zheleznyh rud v glubokikh kar'erakh. Kyiv: Ukraine.

Bubnova, Ye.A. (2017). Vzaimosvyaz' parametrov narusheniya geologicheskoy sredy $\mathrm{s}$ izmeneniyami urovnya podzemnykh vod v rezultate vedeniya gornykh rabot. Metallurgical and Mining Industry, (4), 58-63.

Chetverik, M., Babiy, E., \& Bubnova, E. (2013). The main technical solutions in rational excavation of minerals in open-pit mining. Annual Scientific-Technical Collection Mining of Mineral Deposits, 173-176. https://doi.org/10.1201/b16354-31

Christelis, V., \& Hunges, A.G. (2018). Metamodel-assisted analysis of an integrated model composition: An example using linked surface water - groundwater models. Environmental Modeling and Software, (107), 298-306. https://doi.org/10.1016/j.envsoft.2018.05.004

Committee on Statistics. (2018). Ministry of National Economy of the Republic of Kazakhstan. [online]. Available at: http://stat.gov.kz/

Decka, O., Baroudib, H., Hosnic, A., \& Gueniffey, Y. (2018). A time dependency prediction of the number of mining subsidence events over a large mining field with uncertainties considerations. International Journal of Rock Mechanics and Mining Sciences, (105), 62-72. https://doi.org/10.1016/j.ijrmms.2018.03.010 
Ettmayr, A., Stahl, W., Keller, K., \& Sauer, G. (2000). Dewatering of fine granular materials by vibrating screens with superposed capillary suction. Developments in Mineral Processing: Proceedings of the XXI International Mineral Processing Congress, 5-15. https://doi.org/10.1016/s0167-4528(00)80035-6

Garakani, A.A., Haeri, S.M., Khosravi, A., \& Habibagahi, G. (2015). Hydro-mechanical behavior of undisturbed collapsible loessial soils under different stress state conditions. Engineering Geology, (195), 28-41. https://doi.org/10.1016/j.enggeo.2015.05.026

Kukemilks, K., Wagner, J.-F., Saks, T., \& Brunner, P. (2018). Physically based hydrogeological and slope stability modeling of the Turaida castle mound. Landslides, 15(11), 2267-2278. https://doi.org/10.1007/s10346-018-1038-5

Lapshin, E.S., \& Shevchenko, A.I. (2012). Matematicheskoe modelirovanie kinetiki grohocheniya i obezvogivaniya mineralnogo syriya. Naukovo-Tekhnichnyi Zbirnyk Natsionalnoho Hirnychoho Universytetu, 51(92), 55-64.

Lapshin, E.S., \& Shevchenko, A.I. (2013). Ways of improvement of vibrational segregation and dehydration of mineral raw materials. Naukovyi Visnyk Natsionalnoho Hirnychoho Universytetu, (3), 45-51.

Malizia, J.P., \& Shakoor, A. (2018). Effect of water content and density on strength and deformation behavior of clay soils. Engineering Geology, (244), 125-131.

https://doi.org/10.1016/j.enggeo.2018.07.028

Medvedeva, O. (2015). Development and exploitation of storages of enrichment process wastes as anthropogenic deposits. New Developments in Mining Engineering 2015: Theoretical and Practical Solutions of Mineral Resources Mining, 567-573. https://doi.org/10.1201/b19901-98

Naduty, V., Malanchuk, Z., Malanchuk, E., \& Korniyenko, V. (2015). Modeling of vibro screening at fine classification of metallic basalt. New Developments in Mining Engineering 2015: Theoretical and Practical Solutions of Mineral Resources Mining, 441-443.

https://doi.org/10.1201/b19901-77
Pavlychenko, A., \& Kovalenko, A. (2013). The investigation of rock dumps influence to the levels of heavy metals contamination of soil. Annual Scientific-Technical Collection Mining of Mineral Deposits, 237-238. https://doi.org/10.1201/b16354-44

Petlovanyi, M.V., \& Medianyk, V.Y. (2018). Assessment of coal mine waste dumps development priority. Naukovyi Visnyk Natsionalnoho Hirnychoho Universytetu, (4), 28-35. https://doi.org/10.29202/nvngu/2018-4/3

Rakishev, B.R., Seituly, K., \& Kovrov, O.S. (2014). Physical modeling geomechanical stability of internal overburden dumps. Beijing International Symposium on Land Reclamation and Ecological Restoration LRER 2014, (1), 583-588.

Shashenko, O.M., \& Kovrov, O.S. (2016). Comparative analysis of two failure criteria for rocks and massifs. Naukovyi Visnyk Natsionalnoho Hirnychoho Universytetu, (6), 54-59.

Shevchenko, V., Shevchenko, G., \& Lebed, G. (2016). Recommended practice for using resource-saving technologies and tools for fine classification of uranium ores by size and refuse dehydration. Mining of Mineral Deposits, 10(1), 69-76. https://doi.org/10.15407/mining10.01.069

State Statistics Service of Ukraine. (2018). Retrieved from http://www.ukrstat.gov.ua/

Zhang, X., Spanjers, H., \& van Lier, J.B. (2013). Potentials and limitations of biomethane and phosphorus recovery from sludges of brackish/marine aquaculture recirculation systems: A review. Journal of Environmental Management, (131), 44-54. https://doi.org/10.1016/i.jenvman.2013.09.016

Zhang, G., Wang, F., Zhang, H., Tang, H., Li, H., \& Zhong, Y. (2018). New stability calculation method for rock slopes subject to flexural toppling failure. International Journal of Rock Mechanics and Mining Sciences, (106), 319-328. https://doi.org/10.1016/i.ijrmms.2018.04.016

Wodzinski, P. (2003). Screening of fine granular material. Coal Preparation, 23(4), 183-211. https://doi.org/10.1080/07349340302258

Wu, Y., Lan, H., Gao, X., Li, L., \& Yang, Z. (2015). A simplified physically based coupled rainfall threshold model for triggering landslides. Engineering Geology, (195), 63-69. https://doi.org/10.1016/j.enggeo.2015.05.022

\title{
ОГЛЯД ГЕОМЕХАНІЧНИХ ПРОБЛЕМ НАКОПИЧЕННЯ І ЗМЕНШЕННЯ ВІДХОДІВ ГІРНИЧОВИДОБУВНОӤ ПРОМИСЛОВОСТІ, ШЛЯХИ ЇХ ВИРІШЕННЯ
}

\author{
М. Четверик, О. Бубнова, К. Бабій, О. Шевченко, С. Молдабаев
}

Мета. Виділення геомеханічних проблем накопичення відходів гірничодобувної промисловості та обгрунтування шляхів їх вирішення з можливістю переробки обводненої техногенної сировини шляхом тонкої класифікації зі зневодненням.

Методика. Для досягнення поставленої мети в роботі використано комплексний підхід, що включає науково-технічний аналіз досліджень щодо накопичення відходів, даних державної статистики, аналітичні дослідження величини ущільнення пластів водомістких порід, що впливає на просідання поверхні, а також стендові експериментальні дослідження зі встановлення залежності зміни вологості й вилучення тонких класів у продуктах грохочення залежно від його тривалості при віброударному грохоченні новим способом для розділення відходів збагачення перед їх складуванням у накопичувач.

Результати. Запропоновано розроблений математичний апарат щодо визначення параметрів геомеханічних процесів у техногенних масивах. Показано, що для зменшення техногенного навантаження та проявів негативних геомеханічних процесів необхідно скоротити площу земель під накопичувачами відходів та обсяги самих накопичуваних відходів видобутку і збагачення. Встановлено залежності комплексу попереднього збагачення від якісних параметрів вихідної сировини та технологічних параметрів обладнання. Виявлено, що мінеральна сировина, сформована 3 широких класів крупності з великим вмістом частинок менше 0.2 мм, традиційними способами зневоднюється до $18-22 \%$ і практично не класифікується.

Наукова новизна. Запропоновано математичну модель кінетики грохочення і зневоднення, що комплексно враховує початковий розподіл часток і рідини за висотою шару матеріалу, що грохочеться, сегрегацію, перемішування, просіювання, особливості вібротранспортування (швидкість, кратність і кількість падінь за період вібротранспортування) та зміну висоти шару, що відрізняється урахуванням взаємного впливу класифікації за крупністю й зневоднення. 
Практична значимість. Наведені залежності можуть бути використані для прогнозування розвитку негативних геомеханічних процесів. Застосування технології, що включає тонку класифікацію, при переробці відходів дозволить підвищити економічну ефективність підприємств; розширити сировинну базу для будівельних, коксохімічних виробництв і енергетики; вирішити проблеми створення додаткових ємностей для складування відходів; значно поліпшити екологічний стан у видобувних і переробних регіонах.

Ключові слова: відходи гірничодобувної промисловості, геомеханічні проблеми, віброударне грохочення, попереднє збагачення

\section{ОБЗОР ГЕОМЕХАНИЧЕСКИХ ПРОБЛЕМ НАКОПЛЕНИЯ И УМЕНЫШЕНИЯ ОТХОДОВ ГОРНОДОБЫВАЮЩЕЙ ПРОМЫШЛЕННОСТИ, ПУТИ ИХ РЕШЕНИЯ}

\section{М. Четверик, Е. Бубнова, Е. Бабий, А. Шевченко, С. Молдабаев}

Цель. Выделение геомеханических проблем накопления отходов горнодобывающей промышленности и обоснование путей их решения с возможностью переработки обводненного техногенного сырья путем тонкой классификации с обезвоживанием.

Методика. Для достижения поставленной цели в работе использован комплексный подход, включающий научно-технический анализ исследований по накоплению отходов, данных государственной статистики, аналитические исследования величины уплотнения пластов водосодержащих пород, влияющей на проседание поверхности, а также стендовые экспериментальные исследования по установлению зависимости изменения влажности и извлечения тонких классов в продуктах грохочения в зависимости от его продолжительности при виброударном грохочении новым способом для разделения отходов обогащения перед их складированием в накопитель.

Результаты. Предложен разработанный математический аппарат по определению параметров геомеханических процессов в техногенных массивах. Показано, что для уменьшения техногенной нагрузки и проявления негативных геомеханических процессов необходимо сократить площадь земель под накопителями отходов и объемы самих накапливаемых отходов добычи и обогащения. Установлены зависимости комплекса предобогащения от качественных параметров исходного сырья и технологических параметров оборудования. Выявлено, что минеральное сырье, сформированное из широких классов крупности с большим содержанием частиц менее 0.2 мм, традиционными способами обезвоживается до 18 - 22\% и практически не классифицируется.

Научная новизна. Предложена математическая модель кинетики грохочения и обезвоживания комплексно учитывающая начальные распределения частиц и жидкости по высоте слоя грохотимого материала, сегрегацию, перемешивание, просеивание, особенности вибротранспортирования (скорость, кратность и количество падений за период вибротранспортирования) и изменение высоты слоя, отличающаяся учетом взаимного влияния классификации по крупности и обезвоживания.

Практическая значимость. Приведенные зависимости могут быть использованы для прогнозирования развития негативных геомеханических процессов. Применение технологии, включающей тонкую классификацию, при переработке отходов позволит повысить экономическую эффективность предприятий; расширить сырьевую базу для строительных, коксохимических производств и энергетики; решить проблемы создания дополнительных емкостей для складирования отходов; значительно улучшить экологическую обстановку в добывающих и перерабатывающих регионах.

Ключевые слова: отходы горнодобывающей промышленности, геомеханические проблемы, виброударное грохочение, предобогащение

\section{ARTICLE INFO}

Received: 22 May 2018

Accepted: 21 November 2018

Available online: 30 November 2018

\section{ABOUT AUTHORS}

Mykhailo Chetveryk, Doctor of Technical Sciences, Head of the Department of Geomechanics of Mineral Opencast Mining Technology, Institute of Geotechnical Mechanics named after M.S. Polyakov of the National Academy of Sciences of Ukraine, 2a Simferopolska St, 49005, Dnipro, Ukraine. E-mail: m.s.chetverik@gmail.com

Olena Bubnova, Candidate of Technical Sciences, Senior Researcher of the Department of Geomechanics of Mineral Opencast Mining Technology, Institute of Geotechnical Mechanics named after M.S. Polyakov of the National Academy of Sciences of Ukraine, 2a Simferopolska St, 49005, Dnipro, Ukraine. E-mail: bubnova@nas.gov.ua

Kateryna Babii, Candidate of Technical Sciences, Senior Researcher of the Department of Geomechanics of Mineral Opencast Mining Technology, Institute of Geotechnical Mechanics named after M.S. Polyakov of the National Academy of Sciences of Ukraine, 2a Simferopolska St, 49005, Dnipro, Ukraine. E-mail: katebabiy@i.ua

Oleksandr Shevchenko, Candidate of Technical Sciences, Senior Researcher of the Department of Geomechanics of Mineral Opencast Mining Technology, Institute of Geotechnical Mechanics named after M.S. Polyakov of the National Academy of Sciences of Ukraine, 2a Simferopolska St, 49005, Dnipro, Ukraine. E-mail: igtm.aishevchenko@gmail.com

Serik Moldabaev, Doctor of Technical Sciences, Professor of the Mining Department, Kazakh National Research Technical University named after K.I. Satpayev, 22 Satbayev St, 050013, Almaty, Kazakhstan. E-mail: moldabaev_s_k@mail.ru 